\title{
DEMOGRAPHIC AND LIFESTYLE ATTRIBUTES WITH A FUNDAMENTAL ROLE IN FOOD SUPPLEMENT CONSUMPTION (EXPLORATORY RESEARCH)
}

\author{
Zsófia Nábrádi \\ (Institute of Marketing and Trade University of Debrecen Faculty of Economics \\ and Business Institute of Marketing and Trade ) \\ 138.Böszörményi út Debrecen 4032 \\ nabradi.zsofia@econ.unideb.hu
}

\begin{abstract}
The worldwide proportion of food supplement consumers has been steadily increasing, more than 50\% of the Hungarian population tends to buy at least one type of dietary supplement. In most cases, the purchase and consumption of food supplements are not based on medical indications but depends on consumers' individual decisions. The study of consumer groups enables the investigation of typicalities which have an impact on attitudes related to the consumption of food additives. The present study explores the demographical factors determining the global consumption of dietary supplements by secondary research. It sought to explore the typical features of consumer lifestyles in line with the research findings, based on previously specified criteria, through qualitative focus group examinations. My study focused on subjects who bought and purchased at least one type of food supplement in the previous year and placed a high emphasis on healthy diet and lifestyle in their everyday lives. The consumption of dietary supplements indicates growth with age and it is more common among women. Consumers with higher qualifications and incomes tend to buy products with vitamins and minerals in a greater proportion. The identification of nutrition factors revealed that the proportion of those who do not need extra nutrient intake is high among food supplement consumers. It is primarily true of women having a healthy lifestyle (they typically consume high amounts of vegetables and fruits, they are physically active, non-smokers and do not use alcohol); moreover, their socio-economic status is typically high. The findings of my quantitative research suggest that the purchase and consumption of dietary supplements are most characteristic of the "Successful", "Quality oriented-successful" and "Loyal to the brand - modest" groups in the lifestyle-based consumer segments. The investigated sample showed ambiguous attitudes towards product quality and willingness to pay in all the three batches. Nevertheless, it can be established, when consumers buy food supplements, brand sensitivity proves to be a dominant factor in addition to - typically Hungarian - price sensitivity. Based on lifestyle factors, the current research may bring us closer to the exploration of the motivational and attitude patterns of consumers' food supplement purchases.
\end{abstract}

Keywords: dietary supplement consumption, lifestyle.

(JEL Code: I12, M31)

\section{INTRODUCTION}

Definition of dietary supplements, consumption patterns

The definition of dietary supplements varies all over the world. DSHEA (Dietary Supplement Health and Education Act) lays down the regulatory framework of dietary supplements in the United States of America. As for its definition, the following are considered dietary supplements:

- elements to supplement diet;

- which do not replace conventional meals;

- may not be marketed as conventional food products;

- can be taken by mouth in the form of capsules, tablets, pastilles or liquid;
- are not considered as homoeopathic products or local applications (BROWN, 2017).

According to the American Food and Drug Administration (FDA), dietary supplements include all (non-tobacco) products to compensate for diets, including one or more ingredients of the following: vitamins, minerals, amino acids, medical plants or other herbal products; and/or the concentrates, ingredients or combinations of these elements. (AKILEN, et al., 2014).

In Hungary, the 37/2004. (IV. capsules, pills 26.) ESZCSM (Ministry of Health, Social and Family Affairs) Decree is in accordance with the EU decree on food supplements. Under the Decree, food supplements are concentrated sources of nutrients or other substances with a nutritional or physiological 
effect, either alone or combined. Supplements may be used to correct conventional diet, and they come in different forms from traditional foodstuffs (LUGASI, 2014).The coherent position of the EU lays down that beneficial claims for food supplements shall be communicated to consumers instead of the reduction of disease risk claims. However, the literature on the subject has highlighted numerous consumer misconceptions and revealed that customers purchase these preparations to treat various kinds of diseases.

Dietary supplements come in various forms and types on the market; however, the present study discusses merely vitamin and nutrient consumption. In 2017, the EUROMONITOR survey found that Hungarians pay increasing attention to preserving their health to avoid severe health problems. Although enriched/functional foods and beverages play an important role on the market, the majority of Hungarian people have higher confidence in the efficiency of tablets (and more specifically in vitamins and minerals) (EUROMONITOR, 2017). A survey by the Nutrition Business Journal on sales in the food supplement industry in 2015 showed that the purchase of dietary supplements including vitamins and minerals accounted for $43 \%$ of total purchases (JOHNSON, 2015). The consumption of vitamins is the most representative in various food supplements. DICKINSON et al. (2014) survey findings suggest that the following products are considered the most popular in America:

Table 1. Most frequently consumed vitamins and minerals in the USA

\begin{tabular}{|l|c|}
\hline Product & Use (\%) \\
\hline Multivitamin & 71 \\
\hline Omega-3 or fish oil & 33 \\
\hline Vitamin D & 32 \\
\hline Vitamin C & 32 \\
\hline Vitamin B complex & 25 \\
\hline Magnesium & 12 \\
\hline Glucosamine/Chondroitin & 12 \\
\hline
\end{tabular}

Source: Author's development based on Dickinson et al. (2014)

Several previous studies have confirmed that the consumption of food supplements is growing with age and is much higher among women (BAILEY et al. 2011, 2013; RADIMER et al. 2004; DICKINSON\&MACKAY, 2014; ROVIRA et al. 2013). The identification of nutrition factors revealed that the proportion of those who do not need extra nutrient intake is high among food supplement consumers. It is primarily true of women having a healthy lifestyle (who typically consume high amounts of vegetables and fruits, are physically active, non-smokers and do not use alcohol); moreover, their socio-economic status is typically high (VANTANPARAST et al., 2010). REEDY et al. (2005) researched the factors of health-conscious behaviour and their findings show that food supplement users tend to consume higher amounts of vegetables and fruits.
An American survey has confirmed that vitamin D intake in high-risk consumer groups (e.g. small children and menopausal women) is critically low (PAJOR et al., 2017). It is true of vitamin consumption through both nutrition and food supplements. In Hungary, data on dietary supplement intake are not available, although a survey on consumer habits has drawn attention to the emerging phenomenon in our country. OGYÉI investigation findings suggest that the vitamin D intake of the population is at a critically low level, equal to the level in their 2009 data. Whereas the intake of certain vitamins (C, B1, B6, B12 and niacin) is consistent with recommendations in Hungary in both genders, it must be underlined that vitamin intake for the great proportion of the population is lower than expected. Interestingly, the survey findings conclude that there is a major divergence between male and female vitamin intake, in favour of men (OGYÉI, 2016).

The survey based on the preceding approximately 20 years carried out by NHANES (National Health and Nutrition Examination Surveys) has made a powerful case that the consumption of food additives is more widespread among those with higher qualifications than those of lower socioeconomic status (DICKINSON\&MACKAY, 2014); the same applies to Hungary. The statement that a considerable proportion of consumers with regular physical activity purchases at least one type of dietary supplement can be considered globally true. The exception to this is a survey made in Mediterranean countries, Girona and Spain (ROVIRA et al., 2013), which failed to find a significant correlation between food supplement consumption and regular physical activity. The examination of other lifestyle factors proves that there is a significant correlation between smoking and the use of food supplements. Therefore, it can be stated that those who smoked previously but quit this habit, are more likely to consume dietary supplements than those who have never smoked or smoke currently (KNUDSEN et al., 2002; DICKINSON \& MACKAY, 2014). Obesity investigations suggest that healthy, overweight and obese individuals consume food supplements in approximately the same proportion. A study by RADIMER at al. (2004) on alcohol consumption have found that individuals who consume wine, beer or short drinks more than four times per month, consume some dietary supplement with higher probability. Their research samples indicate that those who consume alcohol less frequently or never, will use food supplements with lower probability.

BAILEY at al. (2013) findings establish that American adults purchase food supplements to maintain and safeguard their health. However, the purchase of most products fails to follow medical advice, i.e. consumers bring their personal decisions on buying the food supplements. It supports the inverse hypothesis mentioned in several previous research papers that consumers bestow a significant role to dietary supplements in preventing the development of adverse conditions (BAILEY, 2013). 


\section{MATERIALS AND METHODS}

Lifestyle-based consumer segments were developed in Hungary in 2010 (VERES et al., 2010). Veres at al. have explored the demographic factors in specific groups, their attitudes related to purchase, consumption, brands and also their preferred hobbies and spare-time activities. Their research findings enable the formation of three broad categories, which include the following lifestyle groups:

Table 2. Lifestyle categories and included groups

\begin{tabular}{|l|l|}
\hline Consumer "elite" & $\begin{array}{l}\text { Successful } \\
\text { Quality-oriented, successful }\end{array}$ \\
\hline Consumer middle-layer & $\begin{array}{l}\text { Prestige consumer } \\
\text { Stay-at-home, selective } \\
\text { Loyal to the brand, modest }\end{array}$ \\
\hline Who lag behind & $\begin{array}{l}\text { Stay-at-home, lagging } \\
\text { Adventurous, lagging } \\
\text { Conservative, poor }\end{array}$ \\
\hline
\end{tabular}

Source: Author's development based on Veres et al. (2010)

All the above-listed consumer layers include values and attitudes to explain their group membership. These values and attitudes follow the financial positions or consumer statuses to some extent, but they are partially independent of them. Research on attitudes towards food supplement consumption has been unprecedented so far in Hungary. My paper sought to address the question which group(s) appear among consumers and users of food supplements among the previously defined lifestyle segments. My secondary research results indicate that the purchase and use of dietary supplements are significantly higher among consumers with specific demographical and lifestyle features. Accordingly, my research included subjects who satisfied the following criteria:

- consumed at least one type of dietary supplement in the previous year

- have higher education qualifications

- are above 25 years

- healthy nutrition is a priority

- do regular physical activity

My qualitative research - 8 participants (5 women and three men) - was based on focus group interviews, where the scenario was divided into three broad areas. The first part explored attitudes to the purchase and consumption of food supplements. The second part determined lifestyle-based consumer segments, whereas the third one identified group attitudes.

\section{RESULTS AND DISCUSSION}

\section{Attitudes towards food supplement purchase and consumption}

The investigated samples indicate three crucial motivational factors in the use of dietary supplements. In purchasing these preparations, the key drivers are health maintenance and immune system boost. Previous research has underlined numerous consumer misconceptions stating that food supplement intake is suitable for the treatment of certain health issues. In my survey, the relationship between the application of food supplements and disease prevention and/or treatment was the subject of discussions. Research participants were active and they regularly performed some physical exercises. The significance of increasing performance was an outstanding motivational factor for them.

The group members provided homogeneous replies to questions related to dietary supplement consumption. On that basis, it may be considered that the most preferred products include vitamins (especially vitamins $\mathrm{C}, \mathrm{D}, \mathrm{E}, \mathrm{K}$ and multivitamins) and minerals (potassium and magnesium). In purchasing specific products, prices and brands are determinants, whereas the origin of dietary supplements is less influential. Customers buy domestic and import food supplements, attributing higher credibility to specific brands.

Purchase locations are typically pharmacies, drug stores and body shops. Online shopping is also widespread among the group members, although they merely purchase trusted preparations which "work well" for them. Consumers search for information both online and offline; however, a reference person is crucial for them (e.g. a doctor, a dietician, a pharmacist or a trainer). Their willingness to spend on food supplements goes hand in hand with their income levels, although it can be stated that the study group members were all willing to pay a higher purchase price for food supplements.

\section{Identification of lifestyle-based consumer segments and group attitudes}

My research sample matched with three lifestyle segments determined by Veres et al. It can be claimed that the consumer clusters where the purchase and use of dietary supplements were the most typical, consisted of the "Consumer elite", and the "Consumer middle layer" groups. The next section of my paper will describe the three lifestyle groups which showed similarities with the ones identified in Veres et al. research.

\section{"Quality oriented successful"}

Who belong to this group purchase exclusively good quality products, and are loyal to their favorite brands. Their brandchoice is based on quality, they never buy unknown brands. Brands are their key factors for bringing a decision on quality; a certain brand suits them and typical of them. They think that the use or consumption of the chosen brands say a lot about the person. Their brand preferences reflect the choices of their close acquaintances. They often test new products and spend much time on outer appearance, follow fashion, enjoy shopping for clothes. They spend a lot on toiletries and cosmetics, sometimes buy unnecessary products. If they find an attractive product, buy it immediately, regardless of its quality. They like spending time with the family. They spend more time on sports than the average. They are outgoing, likes taking family, friends, acquaintances to restaurants, pubs, discos, etc. They visit friends or invite guests more often than the average. They are active internet users, like 
watching films, listening to popular music and reading weekly newspapers.

Group attitude towards the purchase and use of food supplements. "I only trust a well-established brand, as unknown brands might pose a potential risk to health.

\section{"Successful"}

If they come to like something (e.g. a product), they will be loyal to it, and usually buy the well-known brands. They are loyal to brands believed to be of good quality, as quality is crucial for them. They think that buying a good quality product is more economical, although more costly, as it "will pay off". They like spending free time with the family. If they stay at home, they like watching TV, but not series. They are relatively active internet users. They rather avoid shopping, it is true of both shopping for food and clothes, and "shopping" is not among their preferred activities. Their financial means can be regarded good. They like popular music, printed press and read books rarely.

Group attitude towards the purchase and use of food supplements. "I buy my preferred products; quality is important for me".

\section{"Loyal to brand, modest"}

Their shopping is typically thrifty but they consider brands significant. They buy the well-known brands, and are loyal to preferred brands. They intend to buy merely good quality products, their interest in bargains and sales is lower than the average. They think that buying branded products is much more economical, as quality "will pay off". They test new products very often, spend relatively little on toiletries and cosmetics, but attempt to care about appearance. They usually refuse to pay more for good quality and ignore the brands used in their environment. They spend their free time by going out. Watching TV and series are less frequent for them than the average, but they prefer films. Listening to popular music is very typical of them, they are also regular internet users. Entertainment with family, friends, acquaintances (restaurant, pub, disco, etc.) is considerably more frequent in this group than the average.

Group attitude towards the purchase and use of food supplements. "My shopping is thrifty, I will not pay for good quality, but I am loyal to certain products".

My research identified further lifestyle segments which the respondents regarded strange for themselves. The question sets related to the purchase of food supplements highlight the opinions of the participants: one group can be regarded negative, two ones are neutral, all the others are users of food supplements. The findings are illustrated in the figure below.
Figure 1. Consumption of dietary supplements in specific lifestyle segments.

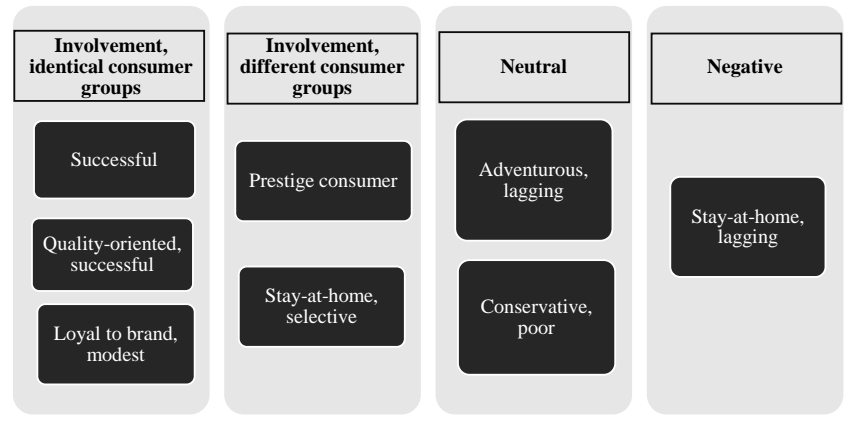

Source: Author's development

Veres et al. carried out an investigation based on education levels and social-statuses in lifestyle groups. My secondary research for the identification of the demographical factors of certain lifestyle groups showed similar results. The findings on the purchase and use of food supplements lead the author to consider the "Stay-at-home lagging" lifestyle group negative. Age-wise, it consists of an older consumer layer with lower or intermediate levels of education, low income and insufficient access to durable goods. The neutral category implies the "Adventurous, lagging" and the "Conservative, poor" groups among lifestyle segments. In terms of educational levels, both groups are about the average; examination on their social status showed heterogeneity, but they fail to show a considerable shift in either direction.

The purchase and use of food supplements are mostly typical of the "Consumer middle layer" and the Consumer elite" segment groups. My research isolated the groups with which my sample showed similarities among the ones involved in purchase and use, displaying different attitude patterns. The study participants and the "Consumer elite" segment group showed the same attitudes. The "Successful" and the "Quality oriented, successful" groups have a higher than average level of education. As for their social status, the "Successful" group represents a higher, whereas the "Quality oriented, successful" a somewhat lower level. It may result from the age factor, as the latter group consisted of primarily young people. In the middle-layer groups, the identification of the "Loyal to brand, modest" group was decisive. It is the youngest group among the lifestyle segments. In the survey by Veres et al. the average age of members was 29.6, whereas they were representing a higher-than-average education level. However, due to their average age (young), their purchase of consumer durables was not regarded significant.

Segments in the "Consumer middle-layer" included groups whose attitudes the participants could not accept, nevertheless they thought that they represented a considerable purchasing power on the market of food supplements. The members of the "Prestige consumer" group are mostly older people, approximating the age of 60. Their education level is average. Their status group belongs to a lower category, and it may stem from the high proportion of pensioners. The "Stay-at-home, selective" group consists of the young middle generation. Their level of education is considerably higher 
than the average. A relatively high proportion of the group is included in the group of high social status.

\section{CONCLUSION}

Lifestyle-based consumer profiles related to the use of dietary supplements have been undiscovered by researchers so far. The purchase and use of food supplements can be considered higher among consumers with specific demographical and lifestyle characteristics. The current investigation sought to disclose consumer attitudes towards food supplements in this social layer. An in-depth study of lifestyle based consumption would be recommendable in various aspects to get a good understanding of consumer layers. Furthermore, quantitative and qualitative research activities can be relevant to gain a sound knowledge of consumer groups and thus the distinctive features of consumption and spending.

\section{ACKNOWLEDGMENT}

This research was supperted by EFOP-3.6.2-16-201700003 Sport, recreaction and health industry cooperation research network

\section{REFERENCES}

Akilen R., Tsiami A., Robinson N. (2014): Individuals at risk of metabolic syndrome are more likely to use a variety of dietary supplement, Advances in Integrative Medicine 1 pp. 131137 Permanent link to this document: http://dx.doi.org/10.1016/j. aimed.2014.12.003

Bailey R. L., Fulgoni V. L., Keast D. R., Dwyer J. T. (2011): Dietary supplement use is associated with higher intakes of minerals from food sources, The American Journal of Clinical Nutrition, 94 (5) pp. 1376-1381 Permanent link to this document: http://dx.doi. org/10.3945/ajcn.111.020289.

Bailey R. L., Gahche J. J., Miller P. E., Thomas P. R., Dwyer J. T. (2013): Why US adults use dietary supplements, JAMA Internal Medicine, 173 (5) pp. 355-361 Permanent link to this document: http://dx.doi.org/10.1001/jamaintermed.2013.2299.

Brown A. C. (2017): An overview of herb and dietary supplement efficacy, safety and government regulations in the United States with suggested improvements. Part 1 of 5 series, Food and Chemical Toxicology 107 pp. 449-471 Permanent link to this document: http://dx.doi.org/101016/j.fct.2016.11.001

Dickinson A., Blatman J., El-Dash N., FrancoJ. C. (2014): Consumer usage and reasons for using dietary supplements: report of a series of surveys, Journal of the American College of Nutrition 33 (2.) pp. 176-182

Dickinson A., MacKay D. (2014): Health habits and other characteristics of dietary supplement users: a review, Nutrition Journal 13:14 Permanent link to this document: https://doi. org/10.1186/1475-2891-13-14

Euromonitor International (2017): Country Report Vitamins in Hungary http://www.euromonitor.com/vitamins-in-hungary/report Johnson J. (2015): NBJ Supplement Business Report: a Tough Year for Supplements by the Numbers http://www.newhope.com/managing-your-business/2015-nbj-supplement-business-report-toughyear-supplements-numbers
Knudsen V.K., Rasmussen L.B., Haraldsdóttir J, Ovesen L, Bülow I, Knudsen N, Jørgensen T, Laurberg P, Perrild H. (2002): Use of dietary supplements in Denmark is associated with health and former smoking, Public Health Nutrition 5 (3) pp. 463-468 Permanent link to this document: https://doi.org/10.1079/PHN2001276

Lugasi A. (2014): Az étrend-kiegészítők kockázati tényezői, Magyar Tudomány 175 (11) 2014/11 pp. 1354-1365

Országos Gyógyszerészeti és Élelmezés-egészségügyi Intézet (OGYÉI) (2016): Étrend-kiegészítők Permanent link to this document: https://www.ogyei.gov.hu/etrend_kiegeszitok/

Pajor E.M., Eggers S.M., Curfs, Oenema A., de Vries H. (2017): Why do Dutch people use dietary supplements? Exploring the role of socio-cognitive and psychosocial determinants, Appetite 114 pp. 161-168 Permanent link to this document: http://dx.doi. org/10.1016/j.appet.2017.03.036

Radimer K., Bindewald B., Hughes J., Ervin B., Swanson C., Picciano M.F. (2004): Dietary Supplement Use by US Adults: Data from the National Health and Nutrition Examination Survey, 1999-2000, American Journal of Epidemiology 160 (4) pp. 339349 Permanent link to this document: https://doi.org/10.1093/aje/ kwh207

Reedy J., Haines P.S., Campbell M.K. (2005): Differences in fruit and vegetable intake among categories of dietary supplement users, Journal of the American Dietetic Association, 105 pp. 17491756 Permanent link to this document: https://doi.org/10.1016/j. jada.2005.08.009

Rovira M. A., Grau M., Castañer O., Covas M.I., Schröder H.; REGICOR Investigators (2013): Dietary supplement use and health-related behaviors in a Mediterranean population, Journal of Nutrition Education and Behavior, 45 (5) pp. 386-391 Permanent link to this document: https://doi.org/10.1016/j.jneb.2012.03.007

Vatanparast H., Adolphe J. L., Whiting S. J. (2010): Socio-economic status and vitamint/mineral supplement use in Canada, Health Reports, 21 (4), pp. 19

Veres Z. (ed) (2010): Életstílus alapú fogyasztói szegmensek Magyarországon, Study Volume, University of Szeged, ISBN 978-963306-071-1 